\title{
Influence of Sage (Salvia Officinalis L.) and Purslane (Portulaca Oleracea L.) on Weight Reduction and Some Biochemical Parameters in Rats Suffering from Obesity
}

\author{
Eman, El-Sayed. M. El-Serwy ${ }^{1}$ and Mohamed, Y. Abd El-Hameid ${ }^{2}$ \\ ${ }^{1}$ Nutrition and Food Science Dept., Faculty of Home Economics, Helwan University. \\ ${ }^{2}$ Home Economics Dept., Faculty of Education, Suez.Canal University. \\ Cairo-Egypt.
}

\begin{abstract}
The present work was conducted to study the effect of Sage (Salvia Officinalis L.) and Purslane (Portulaca Oleracea L.) on the nutritional parameters (including feed intake and body weight gain \%), lipid parameters, glucose, liver enzymes and some hormones (total thyroxin $T_{4}$, triiodothyronine $T_{3}$ and leptin) of rats suffering from obesity. The rats $(n=48)$ were divided into two main groups, the first main group ( $n=6$ rats) fed on basal diet as a control negative group. The second main group( $n=42$ rats) received high fat diet for 6 weeks to induce obesity in rats. After these periods, the mean value of body weight gain \% was estimated in the two main groups, also blood samples were collected from all rats to estimate the levels of cholesterol and triglycerides, then the high fat diet group was divided into (7) subgroups ( $n=6$ rats for each ), the first subgroup fed on high fat diet as a control positive group. Subgroups ( 2 and 3) were fed on high fat diet supplemented with $2 \%$ and $4 \%$ Sage, respectively. Subgroups ( 4 and 5 ) received high fat diet supplemented with $2 \%$ and $4 \%$ Purslane, respectively. Subgroup (6) fed on high fat diet supplemented with $2 \%$ mix $(1 \%$ sage, $1 \%$ Purslane ). The last subgroup was received high fat diet supplemented with $4 \% \operatorname{mix}(2 \%$ sage, $2 \%$ Purslane ). The results cleared that, addition of Sage (Salvia officinalis) or Purslane (Portulaca Oleracea) or mix of them at any tested levels $(2 \%$ or $4 \%)$ to the high fat diet decreased the body weights, in addition to significant decrease in the mean values of serum cholesterol, triglycerides, low-density lipoprotein cholesterol (LDL-c), very low-density lipoprotein (VLDL-c), glucose, aspartate amino transferase (AST) and alanine amino transferase (ALT) in all treated groups, compared to the positive control groups, while high-density lipoprotein (HDLc) increased, also the mean values of $T_{3}, T_{4}$ and leptin hormones were improved. It was concluded that, the mix of sage and purslane at high level (4\%) showed the best effect on body weights, lipid profile, liver functions, glucose level and hormones of obese rats fed on high fat diet.
\end{abstract} Key words: Sage (Salvia officinalis L.), Purslane (Portulaca Oleracea L.), obesity, rats, lipid profile, glucose, liver
enzymes, hormones (leptin, $T_{3}$ and $T_{4}$ ).

\section{Introduction}

Obesity is a medical condition in which excess body fat accumulates to the extent that it may have an adverse effect on health, leading to reduction of life expectancy and/or increased health problems (Kumari et al., 2011). According to data from the World Health Organization (WHO), one billion adults that are approximately overweight currently exist in the world, of which three hundred million are obese. These numbers led to the finding that obesity appears as a major global epidemic, affecting countries in all stages of development (Pereira et al., 2010). Overweight 


\section{Eman, El-Sayed. M. El-Serwy and Mohamed, Y. Abd El-Hameid}

and obesity are the fifth leading risk for global deaths. At least, 2.8 million adults die each year as a result of being overweight or obese (World Health Organization, 2000).

The etiology or cause of obesity is an imbalance between the energy ingested in food and the energy expended. The excess energy is stored in fat cells that enlarge and/or increase in number. It is this hyperplasia and hypertrophy of fat cells that is the pathological lesion of obesity. Enlarged fat cells produce the clinical problems associated with obesity either because of either the weight or mass of the extra fat or because of the increased secretion of free fatty acids and numerous peptides from enlarged fat cells. The consequence of these two mechanisms is related to other diseases, such as diabetes mellitus, gallbladder disease, osteoarthritis, heart disease, and some forms of cancer have relationship with obesity (Bray, 2004), Also, the excess weight may be linked to the genetic heritage of the person, bad eating habits, low activity or, for instance, the endocrine disorders (Pereira et al., 2010).

Evidences are emerging to support that an increasing consumption of herbs are effective strategy for obesity control and weight management. Usage of plants and plant products has potential to keep the increasing prevalence of metabolic syndrome in control. For centuries people across the countries have been using natural products as plant based dietary supplements for weight control (Gosh, 2009). A huge number of herbal supplements are currently present in the market for the management of obesity; medicinal herbal supplements are being extensively utilized due to their effectiveness in managing many chronic disorders. They are cost-effective, and exert less to no toxic side-effects in comparison with many chemically synthesized drugs (Park et al., 2011). Accordingly, recent preliminary reports suggested that herbs with a long history of use and other natural substances are less likely to produce severe toxicity might be effective in reducing appetite and promoting significant weight loss (Amin and Nagy., 2009).

Rayalam et al., (2008) suggested that a variety of natural products, including crude extracts and isolated compounds from plants, can induce body weight reduction and prevent diet-induced obesity. The natural products having anti-obesity effects can be arranged into five categories based on their distinct mechanisms; they may produce (1) decrease lipid absorption, (2) decrease energy intake, (3) increase energy expenditure, (4) decrease pre-adipocyte differentiation and proliferation, or (5) decrease lipogenesis and increase lipolysis (Yun, 2010).

Sage (Salvia officinalis L.) an aromatic plant and one of the widest-spread members of the family Lamiaceae, has been used as a traditional herbal medicine against a variety of diseases. The plant is reported to have multiple pharmacological effects, including antibacterial, antiviral, antiinflammatory, hypoglycemic, fungistatic, antimutagenic, anticancer and antioxidative effects (Lu and Foo., 2001 and Smidling et al., 2008). The leaves of S. officinalis possess some therapeutic effects due to the presence of mainly flavonoids and phenolic compounds (Alkan et al., 2012). Sage is considered nontoxic plant at a recommended daily dosage of 4 - $6 \mathrm{~g}$ of the herb (Blumenthal, 1998).

The plant purslane, in Arabic 'Rejlah', (Portulaca oleraceae L.) is listed in the World Health Organization as one of the most used medicinal plants and widely used in East Mediterranean countries (Isin et al., 2007). It is used as an antibacterial and anti-viral agent, as well as for the treatment of viral hepatitis and diabetes management (Meng and Wu., 2008). Purslane is reported to be rich in linolenic acid and B-carotene and used as a health food for patients with cardiovascular diseases (Liu et al., 2000). It contains several types of vitamins and minerals (Mohammad et al., 2004), fatty acids (Xin et al., 2008). Other constituents include coumarins, flavonoids, alkaloids, saponins, and anthocyanin (Peksel et al., 2006).

The present work was conducted to study the effect of Sage (Salvia Officinalis L.) and Purslane (Portulaca Oleracea L.) on weight loss, lipids profile, liver functions, serum glucose and some hormones (leptin, $T_{3}$ and $T_{4}$ ) of obese rats fed on high fat diet. 
Materials:

\section{Materials and Methods}

- Casein, vitamins, minerals, cellulose and choline chloride were purchased from El-Gomhoreya Company, Cairo,
Egypt.

- Forty eight male albino rats (Sprague Dawley Strain) were obtained from Helwan farm.

- $\quad$ Sage (Salvia officinalis L.) was purchased from local market, Cairo, Egypt.

- Fresh leaves of purslane (Portulaca Oleracea L.) were collected from El-sharkia, Egypt. The leaves were air dried and crushed to coarse powder and used.

\section{Methods:}

The Biological Assay:

Forty eight male albino rats $(200-210 \mathrm{~g})$ were kept in individual stainless steel cages under hygienic conditions and fed one week on basal diet adlibitum for adaptation in the animal house of faculty of Home Economics, Helwan University. The basal diet consisted of $14 \%$ protein from casein ( $\geq 80 \%), 4 \%$ soya oil , $0.25 \%$ choline chloride, $1 \%$ vitamin mixture, $3.5 \%$ salt mixture, $5 \%$ cellulose, $0.18 \% \mathrm{~L}$ - cystine and the remainder is corn starch up to $100 \%$ (Reeves et al ., 1993). The vitamin mixture was prepared according to (A.O.A.C., 1975) and the salt mixture was prepared according to Hegested et al., (1941).

After a period of adaptation on basal diet (one week), the rats $(n=48)$ were divided into two main groups, the first main group ( $n=6$ rats) fed on basal diet and kept as a control negative group. The second main group( $n=42$ rats) received high fat diet for 6 weeks to induce obesity in rats, the high fat diet consisted of $20 \%$ fat ( $19 \%$ beef tallow and $1 \%$ soya oil to provide essential fatty acids) according to (Min et al., 2004), $14 \%$ protein from casein ( $\geq 80 \%), 0.25 \%$ choline chloride, $1 \%$ vitamin mixture, $3.5 \%$ salt mixture, $5 \%$ cellulose, $0.18 \% \mathrm{~L}$ - cystine and the remainder is corn starch (Reeves et al ., 1993). After these periods, the mean value of body weight gain $\%$ was estimated in the two main groups according to this
equation $\quad$ BWG $\%=$ final weight-initial weight $\times 100$

$$
\text { initial weight }
$$

Blood samples were collected from all rats to estimate the levels of cholesterol and triglycerides (healthy rats recorded $79.00 \pm 4.922 \mathrm{mg} / \mathrm{dl}$ cholesterol and $39.722 \pm 3.203 \mathrm{mg} / \mathrm{dl}$ triglycerides), while the second main group recorded (135.878 $\pm 4.750 \mathrm{mg} / \mathrm{dl}$ cholesterol and $68.251 \pm 5.231 \mathrm{mg} / \mathrm{dl}$ triglycerides), then the high fat diet group was divided into seven subgroups ( $n=6$ rats for each ), the first subgroup fed on high fat diet as a control positive group. The second and third subgroups fed on high fat diet supplemented with $2 \%$ and $4 \%$ Sage, respectively. The fourth and fifth subgroups received high fat diet supplemented with $2 \%$ and $4 \%$ Purslane, respectively. Sixth subgroup was fed on high fat diet supplemented with $2 \% \operatorname{mix}(1 \%$ sage and $1 \%$ Purslane). The last subgroup received high fat diet supplemented with $4 \% \operatorname{mix}(2 \%$ sage and $2 \%$ Purslane).

During the experimental period ( 28 days), the diets consumed and body weights were recorded twice weekly. At the end of the experiment, the animals were fasted overnight, then the rats were weighed, anaesthetized and sacrificed, then blood samples were collected from the aorta. The blood samples were centrifuged and serum was separated to estimate some biochemical parameters, i.e. serum cholesterol (Allain et al., 1974), triglycerides (Foster and Dumns., 1973), HDL-c (Lopes - Virella et al., 1977), LDL-C and VLDL-C (Fried wald et al., 1972), glucose (Trinder., 1969), aspartate amino transferase (AST) and alanine amino transferase (ALT) (Reitman and Frankel., 1957), total thyroxin $\left(T_{4}\right)$ was determined according to (Britton et al., (1975), triiodothyronine $\left(T_{3}\right)$ according to (Ahmed et al., 1974) and leptin hormone was measured according to the method of Guillaume and Bjorntorp., (1996). Data was presented as means \pm SD statistically analyzed using one way ANOVA test, $p<0.05$ was used to indicate significance (Steel and Torri., 1980). 


\section{Results and Discussion}

Effect of Sage and Purslane on food intake, body weight gain \% and changes of weight of obese rats.

The effect of sage and purslane on feed intake, body weight gain $\%$ and changes of weight of obese rats are presented in Table (1).

Feed intake (g/day for each rat).

The mean value of feed intake in healthy group fed on basal diet (control -ve group) showed non significant differences compared with obese group fed on high fat diet containing $20 \%$ fat (control +ve group). Feed intake in all obese groups which were treated with any tested levels of sage, purslane or mix of them had non significant differences of mean value at $(p<0.05)$, compared with the normal group (control -ve group), on the other hand, the same treated groups also cleared non significant differences of the mean value for feed intake except group of rats was treated with $2 \%$ sage which showed significant increase, compared with obese group fed on high fat diet containing $20 \%$ fat (control +ve group).

Weight Changes of Obese Rats during the Experimental Period (g).

Table (1) showed the follow-up development in weight of normal, obese and obese rats which were treated with sage or purslane or mix of them during the experiment. Data in this table showed significant decrease $(p<0.05)$ in the weight of normal group (control - ve group) in both of the initial and final of the experimental period, as compared to obese group (control +ve group) and all obese treated groups with the two levels of sage, purslane or mix of them.

Feeding obese groups on high fat diet containing $20 \%$ fat and treated with ( $2 \%$ or $4 \%$ sage), $(2 \%$ or $4 \%$ purslane) and mix of them $(2 \%$ or $4 \%)$ led to significant decrease $(p<0.05)$ in the weight at the final of the experiment, as compared to the positive control group.

Groups of rats which were treated with ( $4 \%$ sage) or $4 \%$ mix of ( $2 \%$ sage and $2 \%$ purslane) recorded the lowest significant decrease $(p<0.05)$ in the mean value of weights, as compared to all other treated groups. 
Table (1):

Effect of Sage and Purslane on feed intake, body weight gain \% and changes of weight of obese rats.

\begin{tabular}{|c|c|c|c|c|}
\hline \multirow{2}{*}{ Groups $\quad$ Parameters } & \multirow{2}{*}{$\begin{array}{l}\text { Feed intake } \\
\text { (g/day) }\end{array}$} & Initial weight & Final weight & \multirow{2}{*}{ BWG\% } \\
\hline & & \multicolumn{2}{|c|}{ g } & \\
\hline Control (-) & $19.000^{a b}$ & $172.500^{\circ}$ & $195.000^{\dagger}$ & $13.035^{\circ}$ \\
\hline \multirow{2}{*}{ Control $(+)$} & $17.750^{b}$ & $\frac{ \pm 6.455}{234.750^{a}}$ & \pm 8.165 & \pm 1.520 \\
\hline & \pm 0.957 & \pm 6.994 & $\begin{array}{l}307.500 \\
\pm 10.408\end{array}$ & $30.983^{a}$ \\
\hline \multirow[t]{2}{*}{$2 \%$ Sage } & $20.000^{a}$ & $237.250^{a}$ & $285.250^{\mathrm{bC}}$ & $\frac{ \pm 1.440^{\circ}}{20.224^{b}}$ \\
\hline & \pm 2.160 & \pm 7.410 & \pm 10.045 & \pm 1.127 \\
\hline \multirow[t]{2}{*}{$4 \%$ Sage } & $18.500^{a b}$ & $236.500^{a}$ & $257.250^{\mathrm{e}}$ & $8.773^{e}$ \\
\hline & \pm 1.732 & \pm 6.557 & \pm 7.365 & \pm 0.666 \\
\hline \multirow[t]{2}{*}{$2 \%$ Purslane } & $18.000^{a b}$ & $236.750^{a}$ & $290.000^{b}$ & $22.500^{\circ}$ \\
\hline & \pm 2.160 & \pm 4.645 & \pm 8.165 & \pm 3.010 \\
\hline \multirow[t]{2}{*}{ 4\% Purslane } & $16.750^{\circ}$ & $236.500^{a}$ & $277.500^{\mathrm{cd}}$ & $17.324^{\mathrm{C}}$ \\
\hline & \pm 1.258 & \pm 3.109 & \pm 6.455 & \pm 1.199 \\
\hline $2 \% \operatorname{mix}(1 \%$ sage, $1 \%$ & $17.000^{\mathrm{ab}}$ & $236.500^{a}$ & $270.000^{d}$ & $14.173^{\mathrm{d}}$ \\
\hline Purslane ) & \pm 1.414 & \pm 3.415 & \pm 4.082 & \pm 1.731 \\
\hline $4 \% \operatorname{mix}(2 \%$ sage, $2 \%$ & $18.500^{a b}$ & $239.250^{a}$ & $249.500^{e}$ & $4.281^{\dagger}$ \\
\hline Purslane ) & \pm 2.380 & \pm 1.258 & \pm 2.645 & \pm 0.607 \\
\hline
\end{tabular}

- Values are expressed as mean $\pm S D$.

- Significant at $p<0.05$ using one way ANOVA test.

- Values which have different letters in each column differ significantly, while those with have similar or partially are not significant.

\section{Body Weight Gain \% (BWG \%)}

Body weight gain \% of obese rats fed on diet containing $20 \%$ fat (control $+v e$ ) increased significantly $p<0.05$, as compared to the negative control group fed on basal diet. On the other side, comparing all treated groups with control +ve group demonstrated significant decrease. Treated groups with $4 \%$ mix of ( $2 \%$ sage and $2 \%$ purslane) resulted in the highest decrease in BWG\%, as compared to (control +ve) and other treated groups.

Leaves of Salvia officinalis $L$. (sage) showed significant inhibitory effect on serum triglyceride elevation in mice and inhibitory activity against pancreatic lipase, which participated in digestion of lipids. Isolated abietan-type diterpene constituents [carnosic acid, camosol, royleanonic acid, and 7-methoxyrosmanol] as a new class of pancreatic lipase inhibitor from the leaves of $\mathrm{S}$. officinalis showed that, camosic acid significantly inhibited triglyceride elevation in mice. Furthermore, camosic acid (CA) reduced the gain of body weight and the accumulation of epididymal fat weight in high fat diet-fed mice after 14 days (Ninomiya et al., 2004). The mice fed CA experienced significant reduced visceral adiposity, in addition to significantly reduced serum triglyceride (TG) and cholesterol levels (Wang et al., 2011).

Abdalla.,(2010) indicated that the anti-obesity actions of purslane ethanolic extract may be due to increased energy expenditure-related fatty liver degradation and decreased fatty acid synthesis and fat intake in the liver. The melatonin concentration in purslane was found to exceed that reported in a number of other fruits and vegetables (Simopouloes et al., 2005). Melatonin has a variety of important functions including direct free radical scavenging and anti-inflammatory properties (Rodriguez et al., 2004). 
Hoyos et al. (2000) showed that increases in total cholesterol and LDL-C were reduced significantly by melatonin administration. Melatonin in purslane extract may play a role in the observed anti-obesity and antidiabetic effects.

\section{Effect of Sage and Purslane on Lipid Fractions of Obese Rats}

The mean values of serum cholesterol, triglycerides, LDL-c and VLDL-c (mg/dl) significantly increased $P<0.05$ for control positive group, in comparison with control negative group. The percentage of increase in cholesterol value was about $74.79 \%$, while HDL-c value $(\mathrm{mg} / \mathrm{dl})$ for control positive group decreased than that of the control negative group by about $48.26 \%$. Addition of Sage or Purslane or mix of them to the high fat diet of obesity rats either at $2 \%$ or $4 \%$ resulted in a significant reduction in cholesterol values. Rats which received high fat diets with the previous concentrations of Sage or Purslane or mix of them had lower mean values of triglycerides, LDL-c and VLDL-c compared with control positive group. On the other hand, the same treated groups of rats had higher mean values of HDL-c than that of the control positive group. The best result for lipid fractions was noticed in the group of rats fed on high fat diet containing $4 \%$ mix of ( $2 \%$ sage and $2 \%$ purslane), followed by group that treated with $2 \%$ mix of ( $1 \%$ sage and $1 \%$ Purslane), $4 \%$ Purslane and finally group of rats treated with $4 \%$ Sage (Table 2 ).

Our results are in agreement with many studies which showed that, an improvement in lipid profile was observed with lower plasma LDL cholesterol and total cholesterol levels as well as higher plasma HDL cholesterol levels during and two weeks after treatment with sage (Carla et al., 2009), also sage extract lowered the blood levels of triglyceride and VLDL levels, this effects may due to Salvia Officinalis L. (sage) leaves have PPAR Y agonistic, pancreatic lipase and lipid absorption inhibitory, antioxidant, lipid peroxidation inhibitory and antiinflammatory effects (Kianbakht et al., 2011). The leaves of S. officinalis possess the therapeutic effects due to the presence of mainly flavonoids; phenolic compounds such as camosic, rosmarinic, caffeic, and salvianolic acids; and other phenolic compounds (Alkan et al.,2012).

Many studies have demonstrated various pharmacological effects of Purslane including hypocholesterolemic and antioxidant effects (Chen et al., 2007). Purslane could significantly reduce serum total cholesterol (TC), triglyceride (TG), Malondialdehyde (MDA) content (Xiao-xu et al., 2011), While an increase level of HDL-C was cleared (Abdalla.,2010). Serum total cholesterol decreased in all groups treated with purslane extract. Its was also found that low density lipoprotein cholesterol (LDL-C) decreased significantly in all of the groups treated with purslane extract with respect to positive control group (hypercholesterolemic). These findings indicate that this plant may be useful for the treatment of hypercholesterolemia (Movahedian et al., 2007). 
Table (2):

Effect of Sage and Purslane on lipid fractions of obese rats.

\begin{tabular}{|c|c|c|c|c|c|}
\hline \multirow{2}{*}{ Groups } & Cholesterol & Triglycerides & HDL-c & LDL-C & VLDL-C \\
\hline & \multicolumn{5}{|c|}{$\mathrm{mg} / \mathrm{dl}$} \\
\hline Control (-) & $\begin{array}{l}84.682^{e} \\
\pm 5.377\end{array}$ & $\begin{array}{l}41.250^{1} \\
\pm 2.179\end{array}$ & $\begin{array}{l}44.488^{a} \\
\pm 4.228\end{array}$ & $\begin{array}{l}31.944^{h} \\
\pm 0.815\end{array}$ & $\begin{array}{l}8.250^{\dagger} \\
\pm 0.435\end{array}$ \\
\hline Control (+) & $\begin{array}{l}148.013^{a} \\
\pm 5.502\end{array}$ & $\begin{array}{l}79.665^{a} \\
\pm 6.008 \\
\end{array}$ & $\begin{array}{l}23.020^{d} \\
\pm 2.264\end{array}$ & $\begin{array}{l}109.059^{a} \\
\pm 2.420\end{array}$ & $\begin{array}{l}15.932^{a} \\
\pm 1.201\end{array}$ \\
\hline $2 \%$ Sage & $\begin{array}{l}125.839^{b} \\
\pm 5.188\end{array}$ & $\begin{array}{l}68.638^{b} \\
\pm 4.071\end{array}$ & $\begin{array}{l}31.877^{c} \\
\pm 3.164\end{array}$ & $\begin{array}{l}80.234^{b} \\
\pm 1.957\end{array}$ & $\begin{array}{l}13.727^{b} \\
\pm 0.814\end{array}$ \\
\hline $4 \%$ Sage & $\begin{array}{l}113.615^{c} \\
\pm 4.834\end{array}$ & $\begin{array}{l}59.927^{\text {cd }} \\
\pm 4.246\end{array}$ & $\begin{array}{l}37.132^{6} \\
\pm 3.491\end{array}$ & $\begin{array}{l}64.498^{\mathrm{d}} \\
\pm 0.980\end{array}$ & $\begin{array}{l}11.985^{c d} \\
\pm 0.849\end{array}$ \\
\hline $2 \%$ Purslane & $\begin{array}{l}115.292^{c} \\
\pm 1.620\end{array}$ & $\begin{array}{l}64.150^{b c} \\
\pm 0.963\end{array}$ & $\begin{array}{l}31.853^{c} \\
\pm 1.002\end{array}$ & $\begin{array}{l}70.608^{c} \\
\pm 1.736\end{array}$ & $\begin{array}{l}12.829^{b C} \\
\pm 0.192\end{array}$ \\
\hline $4 \%$ Purslane & $\begin{array}{l}100.521^{\mathrm{d}} \\
\pm 4.549\end{array}$ & $\begin{array}{l}56.520^{d e} \\
\pm 6.149\end{array}$ & $\begin{array}{l}37.987^{\circ} \\
\pm 2.504\end{array}$ & $\begin{array}{l}51.230^{1} \\
\pm 1.181\end{array}$ & $\begin{array}{l}11.303^{\mathrm{de}} \\
\pm 1.230\end{array}$ \\
\hline $\begin{array}{l}2 \% \operatorname{mix}(1 \% \text { sage, } 1 \% \\
\text { Purslane ) }\end{array}$ & $\begin{array}{l}103.534^{\mathrm{d}} \\
\pm 3.443\end{array}$ & $\begin{array}{l}53.215^{\mathrm{e}} \\
\pm 2.061\end{array}$ & $\begin{array}{l}36.010^{b C} \\
\pm 2.770\end{array}$ & $\begin{array}{l}56.881^{e} \\
\pm 0.261\end{array}$ & $\begin{array}{l}10.643^{\mathrm{e}} \\
\pm 0.412\end{array}$ \\
\hline $\begin{array}{l}4 \% \operatorname{mix}(2 \% \text { sage }, 2 \% \\
\text { Purslane ) }\end{array}$ & $\begin{array}{l}89.210^{e} \\
\pm 2.075\end{array}$ & $\begin{array}{l}42.180^{\dagger} \\
\pm 2.517\end{array}$ & $\begin{array}{l}37.368^{b} \\
\pm 2.137\end{array}$ & $\begin{array}{l}43.405^{9} \\
\pm 0.566\end{array}$ & $\begin{array}{l}8.436^{1} \\
\pm 0.503\end{array}$ \\
\hline
\end{tabular}

- Values are expressed as mean $\pm S D$. - Significant at $p<0.05$ using one way ANOVA test.

- Values which have different letters in each column differ significantly, while those with have similar or partially are not significant.

\section{Effect of Sage and Purslane on some liver enzymes and serum glucose of obese rats.}

Concerning aspartate and alanine amine transaminase (AST and ALT), it could be observed that the rats in control negative group had a significant lower mean values than that of control positive group (obese rats) as the following ( $46.047 \pm 4.035$ and $21.440 \pm 2.677 \mathrm{u} / \mathrm{l}$ vs. $76.810 \pm 4.833$ and $43.648 \pm 3.460 \mathrm{u} / \mathrm{l}$, respectively). Xiao-xu et al., (2011) cleared long-term high-fat diet could cause different degrees of degeneration of the livers (table 3 ). When Sage or Purslane was added to the high fat diet of obese rats a significant decrease of AST and ALT values were noticed in comparison to control positive group. On the other hand, high levels of Sage or Purslane or high mix level of them induced significant decrease than other groups that received the low levels. So, the best results was for group of rats fed on $4 \%$ mix of ( $2 \%$ sage, $2 \%$ Purslane).

Lima et al., (2005) reported that, rosmarinic acid and luteolin-7-glucoside are the two most representative phenolic compounds present in $S$. officinalis. These phenolic compounds showed protective effects against oxidative damage in hepatocytes (Lima et al., 2006). The whole plant contains several antioxidants such as water-soluble compounds; salvianolic acid A, salvianolic acid B and rosmarinic acid, tanshinone IIA and several phenolic glycosides. Pre-treatment with extract of three Salvia officinalis doses reduced the $\mathrm{CCl}_{4}$-induced elevation of serum ALT and AST activities, but the highest ALT and AST reduction was observed in group with highest dose of Salvia officinalis (Maryam et al., 2011). Carnosic acid (phenolic compound present in sage) had a dramatic effect on the liver by reducing the hepatic TG content, thus decreasing serum alanine aminotransferase levels (Wang et al., 2011).

Purslane could significantly reduce serum Aspartate Aminotransferase (AST), Alanine and Aminotransferase (ALT) activity (Xiao-xu et al., 2011). Purslane is a potent antioxidant and is reported to contain omega-3 fatty acids (Mohamed and Hussein, 1994) and an excellent source of the antioxidant vitamins $\alpha$-tocopherol, ascorbic acid and $\beta$ carotene, as well as glutathione. The decreased activity of the liver enzymes, ALT, AST, Y-GT and ALP in purslane 


\section{Eman, El-Sayed. M. El-Serwy and Mohamed, Y. Abd El-Hameid}

treated group were possibly due to the antioxidants present in purslane which act against oxidative stress, indicates its protective role against liver damage (Dkhil et al.,2011 and Abdalla., 2010).

Table (3):

Effect of Sage and Purslane on some liver enzymes and serum glucose of obese rats.

\begin{tabular}{|c|c|c|c|}
\hline \multirow{2}{*}{ Groups } & AST & $\mathrm{ALT}$ & \multirow{2}{*}{$\begin{array}{c}\text { Glucose } \\
\mathrm{mg} / \mathrm{dl}\end{array}$} \\
\hline & \multicolumn{2}{|c|}{$\mathrm{u} / \mathrm{l}$} & \\
\hline Control (-) & $\begin{array}{l}46.047^{\mathrm{d}} \\
\pm 4.035\end{array}$ & $\begin{array}{l}21.440^{1} \\
\pm 2.677\end{array}$ & $\begin{array}{l}90.427^{\mathrm{e}} \\
\pm 3.461\end{array}$ \\
\hline Control (+) & $\begin{array}{l}76.810^{a} \\
\pm 4.833\end{array}$ & $\begin{array}{l}43.648^{a} \\
\pm 3.460\end{array}$ & $\begin{array}{l}151.636^{a} \\
\pm 5.318\end{array}$ \\
\hline $2 \%$ Sage & $\begin{array}{l}67.395^{b} \\
\pm 2.820\end{array}$ & $\begin{array}{l}34.627^{b} \\
\pm 2.964\end{array}$ & $\begin{array}{l}129.209^{b} \\
\pm 4.179\end{array}$ \\
\hline $4 \%$ Sage & $\begin{array}{l}57.051^{\mathrm{c}} \\
\pm 4.238\end{array}$ & $\begin{array}{l}31.413^{b c} \\
\pm 2.601\end{array}$ & $\begin{array}{l}116.358^{\mathrm{C}} \\
\pm 6.988\end{array}$ \\
\hline $2 \%$ Purslane & $\begin{array}{l}64.991^{D} \\
\pm 4.038\end{array}$ & $\begin{array}{l}31.850^{\mathrm{bC}} \\
\pm 2.185\end{array}$ & $\begin{array}{l}119.737^{c} \\
\pm 1.116\end{array}$ \\
\hline $4 \%$ Purslane & $\begin{array}{l}56.192^{c} \\
\pm 3.590\end{array}$ & $\begin{array}{l}29.374^{\text {cd }} \\
\pm 2.903\end{array}$ & $\begin{array}{l}104.311^{d} \\
\pm 4.531\end{array}$ \\
\hline $\begin{array}{l}2 \% \operatorname{mix}(1 \% \text { sage, } 1 \% \\
\text { Purslane ) }\end{array}$ & $\begin{array}{l}59.252^{c} \\
\pm 3.388\end{array}$ & $\begin{array}{l}26.100^{\mathrm{de}} \\
\pm 2.425\end{array}$ & $\begin{array}{l}90.870^{\mathrm{e}} \\
\pm 13.209\end{array}$ \\
\hline $\begin{array}{l}4 \% \operatorname{mix}(2 \% \text { sage }, 2 \% \\
\text { Purslane ) }\end{array}$ & $\begin{array}{l}49.934^{d} \\
\pm 3.148\end{array}$ & $\begin{array}{l}24.886^{\mathrm{ef}} \\
\pm 2.177\end{array}$ & $\begin{array}{l}93.718^{\mathrm{e}} \\
\pm 1.983\end{array}$ \\
\hline
\end{tabular}

- Values are expressed as mean $\pm S D$.

- Significant at $p<0.05$ using one way ANOVA test.

- Values which have different letters in each column differ significantly, while those with have similar or partially are not significant.

Also, it could be noticed that, the mean values of serum glucose levels $(\mathrm{mg} / \mathrm{dl})$ for all treated groups were decreased significantly, as compared to the positive control group, but the finest results were for groups of rats that fed on diet contained $4 \%$ mix of $(2 \%$ sage and $2 \%$ Purslane) and group of rats received $2 \%$ mix of $(1 \%$ sage and $1 \%$ Purslane ) Table (3).

This results are in agreement with Clegg et al.,(2011) who demonstrated that consumption of a high-fat (HF) diet impaired the central actions of insulin so, led to central insulin resistance. Plasma glucose levels was increased after 8 weeks for rats fed with the high fat diet (Abdalla., 2010). Common sage (Salvia officinalis) is among the plants to which antidiabetic properties (Baricevic \& Bartol, 2000) have been attributed by popular medicine and its extracts showed to possess hypoglycaemic effects in normal and diabetic animals (Eidi et al., 2005 and Alarcon-Aguilar and collaborators., 2002). Sage tea drinking improved lipid profile and increased antioxidant defenses which may indirectly improve the diabetic condition (Carla et al., 2009). Carnosic acid (phenolic compound present in sage) significantly improved glucose tolerance (Wang et al., 2011).

Many studies have demonstrated various pharmacological effects of Purslane including hypoglycaemic effect (Chen et al., 2007). The effect of purslane extract in diabetic rats decreased the serum glucose level and increased the insulin level in rats model (Gong et al. 2009). Plasma glucose levels in purslane (150 and $300 \mathrm{mg} / \mathrm{kg} \mathrm{bw}$ ) treated groups were also markedly decreased by $28.4 \%$ and $36.4 \%$, respectively when compared to the high fat diet control group may partially due to the improvement in insulin resistance. (Abdalla., 2010). Bioactives found in purslane are dopamine, 
dopa, coumarins, alkaloids and saponins (Sakai et al., 1996), polyphenols, flavonoids and anthocyanin (Peksel et al., 2006). These compounds may influence glucose metabolism by several mechanisms, such as inhibition of carbohydrate digestion and glucose absorption in the intestine, stimulation of insulin secretion from the pancreatic ß-cell, modulation of glucose release from liver, activation of insulin receptors and glucose uptake in the insulinsensitive tissues, and modulation of hepatic glucose output. (Abdalla., 2010).

\section{Effect of Sage and Purslane on Some Serum Hormones of Obese Rats.}

Data at Table (4) showed that, the mean values of serum triiodothyronine $\left(T_{3}\right)$, total thyroxin $\left(T_{4}\right)$ and leptin hormone significantly increased $\mathrm{P}<0.05$ for control positive group, in comparison with control negative group.

In this respect, there are agreement with our results and Koritschoner et al., (2001) who indicated that, experiments on animals have shown a correlation between thyroid hormones and changes in weight. In obese children, serum concentrations of thyroid hormones (TSH, T3, T4) were on average above those of the children of normal weight Reinehr and Andler (2002). Srinivasan et al., (1999) cleared that, increased thyroid hormone concentrations could point to hormone resistance, similar to insulin resistance in obesity. Leptin is a hormone secreted primarily by adipocytes and is present in serum in direct proportion to the amount of adipose tissue (Considine et al., 1996). The primary role of leptin is to provide the central nervous system with a signal of energy (adipose) stores in the body to enable the brain to make the adjustments necessary to balance energy intake and expenditure (Spiegelman and Flier 2001). Our results are in agreement with Enriori et al., (2006) who showed that, in common obesity, leptin loses the ability to inhibit energy intake and increase energy expenditure; this is termed leptin resistance, so found in the blood with high level .

Rats which received high fat diets with addition of sage or purslane or mix of them at any tested levels $2 \%$ or $4 \%$ had lower mean values of serum triiodothyronine $\left(T_{3}\right)$, total thyroxin $\left(T_{4}\right)$ and leptin hormone compared with control positive group. The best result of serum triiodothyronine $\left(T_{3}\right)$, total thyroxin $\left(T_{4}\right)$ and leptin hormone among all treated groups was observed in the group of rats fed on high fat diet containing $4 \%$ mix of ( $2 \%$ sage and $2 \%$ purslane), followed by group that treated with $2 \%$ mix of ( $1 \%$ sage and $1 \%$ Purslane) and finally group of rats treated with $4 \%$ Purslane .

Hence, there are a strong relation between using herbs as way in weight reduction and automatically consequent reduction of serum hormones in the obese case. Our results were in agreement with Reinehr and Andler., (2002) who indicated that, a reduction in overweight or obesity showed a significant decrease in $T_{3}, T_{4}$ and leptin serum concentrations. In this respect, evidences are emerging to support that an increasing consumption of herbs are effective strategy for obesity control and weight management (Gosh., 2009). 
Eman, El-Sayed. M. El-Serwy and Mohamed, Y. Abd El-Hameid

Table (4):

Effect of Sage and Purslane on some serum hormones of obese rats.

\begin{tabular}{|c|c|c|c|}
\hline \multirow{2}{*}{ Groups } & T3 & T4 & \multirow{2}{*}{$\begin{array}{r}\text { Leptin } \\
\mathrm{mg} / \mathrm{dl}\end{array}$} \\
\hline & \multicolumn{2}{|c|}{$\mathrm{nmol} / \mathrm{l}$} & \\
\hline Control (-) & $\begin{array}{l}0.946^{\dagger} \\
\pm 0.050\end{array}$ & $\begin{array}{l}31.346^{e} \\
\pm 2.495\end{array}$ & $\begin{array}{l}1.456^{9} \\
\pm 0.593 \\
\end{array}$ \\
\hline Control $(+)$ & $\begin{array}{l}2.656^{a} \\
\pm 0.150\end{array}$ & $\begin{array}{l}81.443^{a} \\
\pm 3.098\end{array}$ & $\begin{array}{l}10.666^{a} \\
\pm 0.335\end{array}$ \\
\hline $2 \%$ Sage & $\begin{array}{l}2.233^{b} \\
\pm 0.113\end{array}$ & $\begin{array}{l}49.996^{b} \\
\pm 1.786\end{array}$ & $\begin{array}{l}9.333^{b} \\
\pm 0.0 .165\end{array}$ \\
\hline $4 \%$ Sage & $\begin{array}{l}1.540^{\mathrm{d}} \\
\pm 0.052\end{array}$ & $\begin{array}{l}42.796^{c} \\
\pm 2.090\end{array}$ & $\begin{array}{l}7.920^{\mathrm{d}} \\
\pm 0.203\end{array}$ \\
\hline $2 \%$ Purslane & $\begin{array}{l}1.843^{c} \\
\pm 0.075\end{array}$ & $\begin{array}{l}46.553^{b} \\
\pm 1.260\end{array}$ & $\begin{array}{l}8.667^{c} \\
\pm 0.577\end{array}$ \\
\hline $4 \%$ Purslane & $\begin{array}{l}1.370^{\mathrm{e}} \\
\pm 0.075\end{array}$ & $\begin{array}{l}41.970^{\mathrm{cd}} \\
\pm 2.637\end{array}$ & $\begin{array}{l}7.633^{e} \\
\pm 0.287\end{array}$ \\
\hline $\begin{array}{l}2 \% \operatorname{mix}(1 \% \text { sage, } 1 \% \\
\text { Purslane ) }\end{array}$ & $\begin{array}{l}1.240^{\mathrm{e}} \\
\pm 0.060\end{array}$ & $\begin{array}{l}40.216^{\mathrm{cd}} \\
\pm 1.513\end{array}$ & $\begin{array}{l}6.576^{1} \\
\pm 0.157\end{array}$ \\
\hline $\begin{array}{l}4 \% \operatorname{mix}(2 \% \text { sage }, 2 \% \\
\text { Purslane })\end{array}$ & $\begin{array}{l}1.063^{\dagger} \\
\pm 0.090\end{array}$ & $\begin{array}{l}38.176^{d} \\
\pm 1.580\end{array}$ & $\begin{array}{l}6.150^{1} \\
\pm 0.160\end{array}$ \\
\hline
\end{tabular}

- Values are expressed as mean $\pm S D$.

- Significant at $p<0.05$ using one way ANOVA test.

- Values which have different letters in each column differ significantly, while those with have similar or partially are not significant.

\section{Conclusion}

In conclusion, consumption of Sage or Purslane or mix of them at certain levels $(2 \%$ and $4 \%)$ in this study may be useful for treatment of obesity as it lowers body weight, lipid profile, liver functions, glucose level and hormones of obesity induced rats fed on high fat diet. Further studies are recommended to determine the medicinal effect of other different fractions of Sage and Purslane extract. 


\section{References}

A. O. A. C. (1975).

Official Methods of Analysis of Assoc. of official agricultural chemists, $12^{\text {th }}$ ed. Washington, D. C.

Abdalla, H. M. (2010).

Purslane Extract Effects on Obesity-Induced Diabetic Rats Fed a High-Fat Diet. Mal. J. Nut.; 16(3):419-429.

Ahmed, M.; Doe, R.P. and Nuttall, F.Q. (1974).

Triiodothyronine thyrotoxicosis following iodide ingestion: A case report. J. Clin. Endocrinol. Metab.; 38: 574-576.

Alarcon-Aguilar, F.J.; Roman-Ramos, R.; Flores-Saenz, J.L. and Aguirre-Garcia, F. (2002).

Investigation on the hypoglycaemic effects of extracts of four Mexican medicinal plants in normal and alloxandiabetic mice. Phytother. Res.; 16: 383-386.

Alkan, U.F.; Feraye, E. G.; Atila, A. and Mustafa, O. (2012).

Protective effects of Salvia officinalis extract against cyclophosphamide-induced genotoxicity and oxidative stress in rats.Turk. J. Vet. Anim. Sci.; 36 (6): 646-654.

Allain, C.; Poon, L. and Chan, C. (1974).

Enzymatic determination of total serum cholesterol. Clin. Chem.; 20:470-475.

Amin, K. A. and Nagy, M. A. (2009).

"Effect of Carnitine and Herbal Mixture Extract on Obesity Induced by High Fat Diet in Rats," Diabetology \& Metabolic Syndrome; 1 (17): 1-14.

Baricevic, D. and Bartol ,T. (2000).

The biological/pharmacological activity of the Salvia genus. In SAGE - The Genus Salvia; pp. 143-184.

Blumenthal, M. (1998).

The Complete German Commission E Monographs: Therapeutic Guide to Herbal Medicines. American Botanical Council. Austin, TX.

Bray, A. G. (2004).

Medical Consequences of Obesity. The Journal of Clinical Endocrinology \& Metabolism; 89(6):2583-2589.

Britton, K.E.; Ouinn, V.; Brown, B.I. and Ekins, R.P. (1975).

A strategy for thyroid function tests. Br. Med. J.; III: 350-352.

Carla, M. S.; Alice, A.; Ramos, Marisa, F.; Azevedo, Cristovao, F.; Lima; Manuel, F. and Cristina, P. (2009).

Sage Tea Drinking Improves Lipid Profile and Antioxidant Defences in Humans. Int. J. Mol. Sci.; 10: 3937-3950.

Chen, Y.; Shen, Z. and Chen, X. (2007).

Evaluation of free radicals scavenging and immunity-modulatory activities of Purslane polysaccharides. J. Food Composit. Anal.; 22:303-306. 


\section{Eman, El-Sayed. M. El-Serwy and Mohamed, Y. Abd El-Hameid}

Clegg, D.J.; Gotoh, K.; Kemp, C.; Wortman, M.D.; Benoit, S.C.; Brown, L.M.; D'Alessio, D.; Tso, P.; Seeley, R.J. and Woods, S.C. (2011).

Consumption of a high-fat diet induces central insulin resistance independent of adiposity. Physiol. Behav.; 18; 103(1):10-6.

Considine, R. V.; Sinha, M. K. and Heiman, M. L. (1996).

Serum immunoreactive-leptin concentrations in normal-weight and obese humans. N. Engl. J. Med.; 334: $292-$ 295.

Dkhil, A.M; Abdel Moniem. A E.; Al-Quraishy, S. and Saleh,A.R. (2011).

Antioxidant effect of purslane (Portulaca oleracea) and its mechanism of action. Journal of Medicinal Plants Research; 5 (9): 1589-1563.

Eidi, M.; Eidi, A. and Zamanizadeh, H. (2005).

Effect of Salvia officinalis L. leaves on serum glucose and insulin in healthy and streptozotocin-induced diabetic rats. J. Ethnopharmacol.; 100: 310-313.

Enriori ,J. P.; Evans, E . A.; Sinnayah , P. and Cowley ,M,A. (2006). Leptin Resistance and Obesity. Obesity; 14 : 254S-258S.

Foster, L. B. and Dumns, T. T. (1973).

Determination of triglycerides. J. Clin. Chem.; 19:338-353.

Fried wald, W. T.; Leve, R. I. and Fredrickson، D. S. (1972).

Estimation of the concentration of low-density lipoprotein separation by three different methods . Cli. Chem.; 18 . 499-502.

Gong, F. Li. F.;Zhang ,L. Li. J.;Zhang, Z. and Wang, G. (2009):

Hypoglycemic effects of crude polysaccharide from purslane. Int. J. Mol. Sci., 10: 880-888.

Gosh, D. (2009).

"A Botanical Approach to Managing Obesity," University of Wollongong, Wollongong.

Guillaume, M. and Bjorntorp, P. (1996).

Obesity in Children, environmental and genetic aspects. Horm. Metab. Res.; 28, 573-581.

Hegested, D.M.; Mills, C.; Elvehjem, C.A. and Hart, E.B. (1941).

Choline in the nutrition of chicks. J. Biol. Chem.; 138: 459-470.

Hoyos, M.; Guerrero, R.; Cano. J; Olivan, F.; Fabiani, A.; Perganeda, G. and Osuna, C. (2000).

Serum cholesterol and lipid peroxidation are decreased by melatonin in diet induced hypercholesterolemic rats. J. Pineal Res.; 28: 150- 155.

Isin, Y.; Ismail, T.; Askim, H. and Tijen, D. (2007).

Salinity tolerance of (Portulaca oleracea L.) is achieved by enhanced antioxidative system, lower level of lipid peroxidation and proline accumulation. Environ Exp. Bot.; 61:49-57. 
Kianbakht, S.; Abasi, B.; Perham, M. and Hashem, F. (2011).

Antihyperlipidemic Effects of Salvia officinalis L. Leaf Extract in Patients with Hyperlipidemia: A Randomized Double-Blind Placebo-Controlled Clinical Trial. Phytother. Res., 25: 1849-1853.

Koritschoner, N.P.; Alvarez-Dolado, M. and Kurz, S.M. (2001).

Thyroid hormone regulates the obesity gene tub. Embo. Rep.; 2:499-504.

Kumari , P.; Singh,N.; Bhatia, V.; Chawla, And Kumar, D.(2011).

Herbal fight for obesity: a review. International journal of pharmaceutical research and development (I J PRD). 3 (4):193-201.

Lima, C.F.; Andrade, P.B.; Seabra, R.M.; Fernandes-Ferreira, M. and Pereira-Wilson, C. (2005).

The drinking of a Salvia officinalis infusion improves liver antioxidant status in mice and rats. $J$. Ethnopharmacol.; 97: 383-389.

Lima, C.F.; Fernandes-Ferreira, M.; Pereira-Wilson, C. (2006).

Phenolic compounds protect HepG2 cells from oxidative damage: Relevance of glutathione levels. Life Sci., 79 : 2056-2068.

Liu, L.; Howe, P.; Zhou, Y.F.; Xu, Z.Q.; Hocart, C. \& Zhan, R. (2000).

Fatty acids and betacarotene in Australian purslane (Portulaca oleracea) varieties. J. Chromatogr. A 893: 207213.

Lopes-Virella, M. F.; Stone, S.; Ellis, S. and Collwellm J. A. (1977).

Cholesterol determination in high-density lipoproteins separated by three different methods. Clin. Chem.; 23 (5): 882-893.

Lu, Y. and Foo, L.Y. (2001).

Antioxidant activities of polyphenols from sage (Salvia offi cinalis). Food Chem.; 75: 197-202.

Maryam, F.; Soroush, G. and Sahar, G. (2011).

Effects of Salvia officinalis Extract on Carbon Tetrachloride Induced Hepatotoxicity. Global Veterinaria.; 7 (4): 353-357.

Meng, F.B. \& Wu, R.G. (2008).

Appraisal on medicinal values of Portulaca oleracea L. Forest Investig Des.; 1: 77-78.

Min, L.; Ling, S.; Yin, L.; Stephen, C.W.; Randy, J. S.; David, D. and Patrick, T. (2004).

Obesity induced by a high-fat diet down regulates apolipoprotein A-IV gene expression in rat hypothalamus. Am. J. Physiol. Endocrinol Metab.; 287: E366-E370.

Mohamed, A.I. and Hussein, A.S. (1994).

Chemical composition of purslane (Portulaca oleracea). Plant Foods Hum. Nutr.; 45: 1-9.

Mohammad, T. B.; Mohammad, H. B. and Farhad, M. (2004).

Anti-tussive effect of Portulaca oleracea L. in guinea pigs. Iran J. Pharmaceut. Res.; 3: 187-190. 


\section{Eman, El-Sayed. M. El-Serwy and Mohamed, Y. Abd El-Hameid}

Movahedian, A.; Ghannadi, A. and Vashirnia,M.(2007).

Hypocholesterolemic Effects of Purslane Extract on Serum Lipids in Rabbits Fed with High Cholesterol Levels. International Journal of Pharmacology; 3: 285-289.

Ninomiya, K.; Matsuda, H.; Shimoda, H. and Nishida, N.(2004).

Carnosic acid, a new class of lipid absorption inhibitor from sage. Bioorganic \& Medicinal Chemistry Letters. 14 (8): 1943-1946.

Park, J. P.; Kim, J. H.; Park, M. K. and Yun, J. W. (2011)

. "Poten- tial Agents for Cancer and Obesity Treatment with Herbal Medicines from the Green Garden," Biotechnology and Bioprocess Engineering; 16 (6): 1065- 1076.

Peksel, A.; Arisan, I. \& Yanardag. (2006). Antioxidant activities of aqueous extracts of purslane(Portulaca oleracea Subsp. Sativa L.). Ital. J. Food Sci.; 3: 295- 308.

Pereira, A. C. ; Pereira, S. L. L. and Correa, D. A. (2010).

Hoodia gordonii in the treatment of obesity: A review. Journal of Medicinal Plants Research;. 4(22) :2305-2312.

Rayalam, S.; Della-Fera, M.A. and Baile, C.A.( 2008).

Phytochemicals and regulation of the adipocyte life cycle. J. Nutr. Biochem.; $19: 717-726$.

Reeves, P. G.; Nielsen, F. H. and Fahmy, G. C. (1993).

AIN-93 purified diets for laboratory rodents: Final report of the American Institute of Nutrition ad hoc writing committee on the reformulation of the AIN-76A rodent diet. J. Nutr.; 123(11):1939-1951.

Reinehr,T. and Andler, W. (2002).

Thyroid hormones before and after weight loss in obesity. Arch. Dis. Child; 87:320-323.

Reitman, S. and Frankel, S. (1957).

Determination of glutamate pyruvate transferase. Am. J. Clin. Path., 28:56.

Rodriguez, C.; Mayo, J.; Sainz, R.; Antolin, I.; Herrera, F.; Martin, V. and Reiter, R. (2004).

Regulation of antioxidant enzymes: A significant role for melatonin. J. Pineal. Res.; 36: 1-9.

Sakai, N.; Inada, K.; Okamoto, M.; Shizuri, Y.;Fukuyama, Y. and Portuloside, A. (1996).

A monoterpene glucoside, from Portulaca oleracea. Phytochem 42: 1625-1631.

Simopoulos, A.; Tan, D.; Manchester, L. \& Reiter, R. (2005):

A plant source of omega -3 fatty acids and melatonin. J. Pineal. Res.; 39: 331- 332.

Smidling, D., Mitic-Culafic, D., Vukovic-Gacic, B., Simic, D. and Knezevic-Vukcevic, J. (2008).

Evaluation of antiviral activity of fractionated extracts of sage Salvia offi cinalis L. Arch. Biol. Sci.; 60: 421- 429.

Spiegelman, B. M. and Flier, J. S. (2001).

Obesity and the regulation of energy balance. Cell; 104: 531-543. 
Srinivasan, S.R.; Myers, L. and Berenson, G.S. (1999).

Temporal association between obesity and hyperinsulinemia in children, adolescents, and young adults:the Bogalusa Heart Study. Metabolism; 48:928-34.

Steel, R. G. and Torri, J. H. (1980).

Principal and Procedures of Statistical, Biometrical Approach. Pbl. Mc Grew Hill Book Company. $2^{\text {nd }}$ ed. New York, U.S.A.

Trinder, P. (1969).

Determination of glucose in blood using glucose oxidase with an alternative oxygen acceptor. Ann. Clin. Biocheme.; 6: 24-28.

Wang, T.; Takikawa, Y.; Satoh, T.;Yoshioka, Y.; Kosaka, K.; Tatemichi, Y. and Suzuki, K. (2011).

Carnosic acid prevents obesity and hepatic steatosis in ob/ob mice. Hepatology Research; 41: 87-92.

World Health Organization "WHO", (2000).

"Obesity. Preventing and Managing the Global Epidemic, Report of a WHO Con- sultation (WHO Technical Report Series 894).

Xiao-xu, H.; Ya-wei, Z.; Rong-chao, Z.; Qing-shan and Chun-mei, S. (2011).

Protective effect of Purslane on hyperlipidemic rat livers. Journal of Jilin Medical College1.32 (1): 1673-2995.

Xin, H. L.; Xu, Y.F.; Yue, X.Q.; Hou, Y.H.; LI, M. \& Ling, C.Q. (2008).

Analysis of chemical constituents in extract from Portulaca oleracea L. with GC-MS Method (In Chinese). Pharmaceut J. Chin. People's Liberat.; 24: 133-136.

Yun, J.W. (2010).

Possible anti-obesity therapeutics from nature - A review. Phytochemistry; 71 :1625-1641. 


\section{تأثير المريمية والرجلة على انخفاض الوزن وبعض التقديرات البيوكيميائية في الفئران التي تعانى من السمنة}

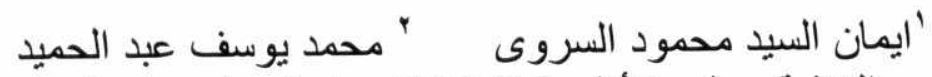

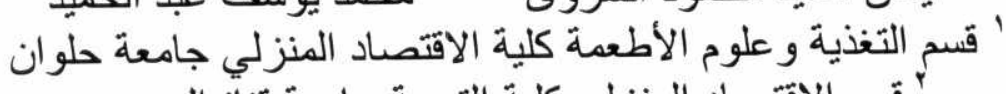

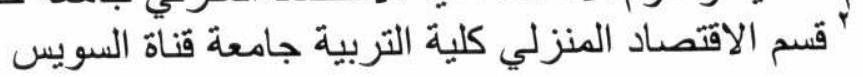

\section{المستخلص العربي}

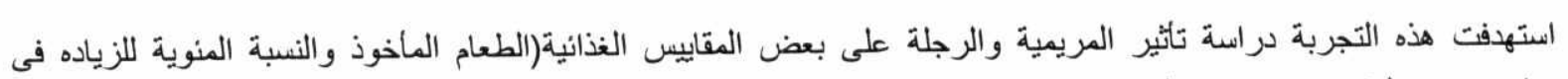

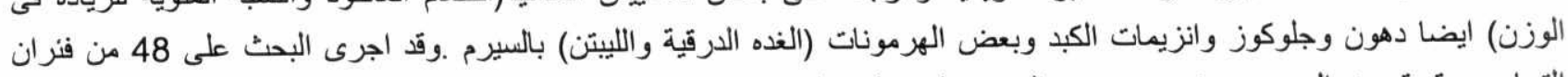

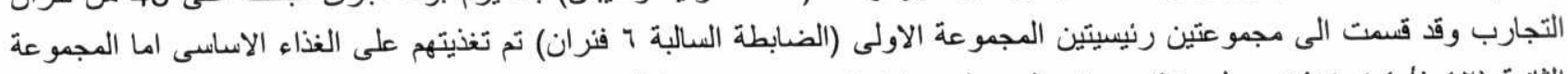

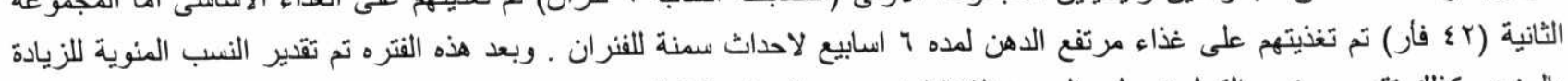

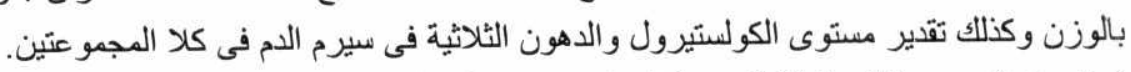

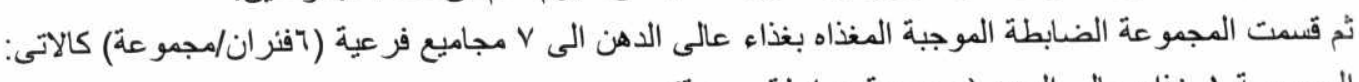

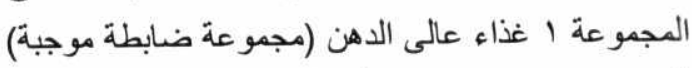

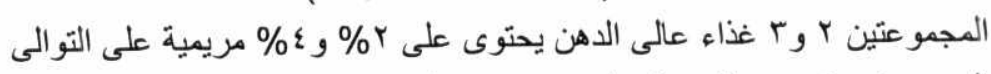

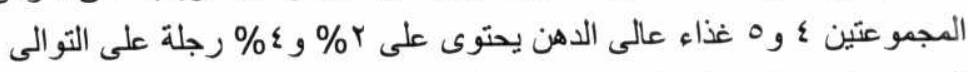

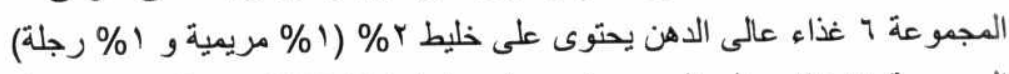

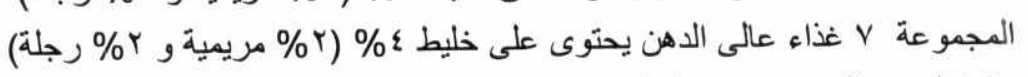

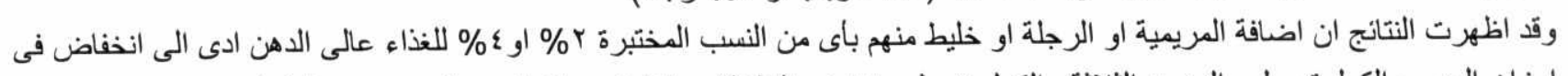

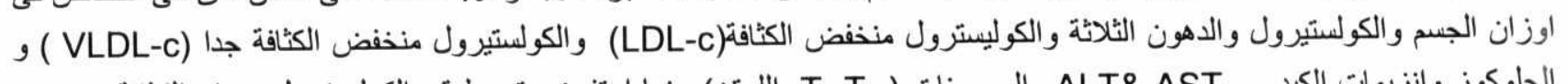

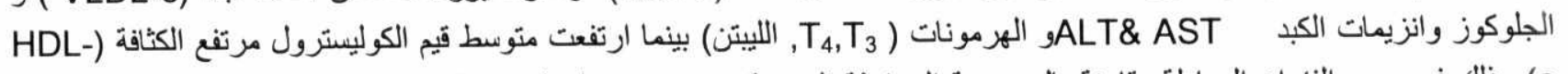

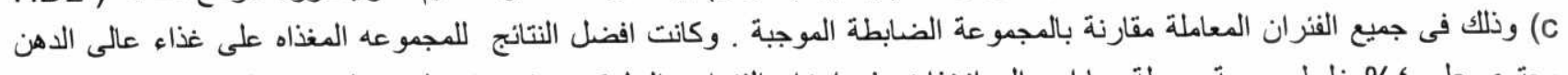

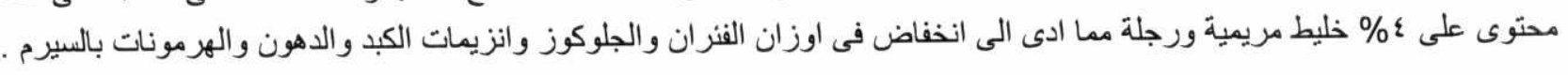

الكلمات المفتاحية: المريمية- الرجلة ـالسمنة_الفتران-الدهون-الجلوكوز -انزيمات الكبد-هرمونات ( T الليبتن). 